\title{
Growth of the white rust fungus Albugo candida in callus tissue of Brassica juncea
}

\author{
INDRANI LAHIRI and T. P. BHOWMIK* \\ Division of Mycology and Plant Pathology, Indian Agricultural Research Institute, New Delhi 110012, India
}

(Received 15 December 1992; revised 19 March 1993; accepted 16 July 1993)

\begin{abstract}
Leaf and stem explants of Brassica juncea cv. Pusa Bold produced callus tissue and plantlets on Murashige and Skoog medium at $18{ }^{\circ} \mathrm{C}$. Among the various organs of inflorescences, systemically infected with Albugo candida, explants from hypertrophied peduncles and thickened terminal leaves proved suitable for the production of dual cultures of the biotroph and its host, success with the former being better than with the latter. Dual cultures were also established from ovaries, but poorly. Infected callus grew faster than its healthy counterpart. Leaf and stem pieces with rust pustules did not form callus. The dual culture showed abundant coenocytic intercellular mycelium, with spherical haustoria within host cells. Infected callus maintained at 15 and $20{ }^{\circ} \mathrm{C}$ for 20 to $30 \mathrm{~d}$ showed only sporangial chains that remained confined within the callus tissue, whereas callus maintained at 25 and $30^{\circ} \mathrm{C}$ contained both sporangia and oospores, like those of $\boldsymbol{A}$. candida found in naturally infected tissues. The pathogen could be maintained in infected callus tissue for prolonged periods by periodic subculturing and it kept pace with the growth of the callus tissue. Placement of an infected callus in close contact with a healthy one did not result in infection of the latter.
\end{abstract}

\section{Introduction}

White rust caused by Albugo candida (Pers. ex. Lev'.) Kunze is an important disease of rapeseed (Brassica campestris L.) and mustard (B. juncea Coss.) in India. The pathogen produces two types of infection: local and systemic. Local infection is characterized by the formation of raised creamy white sporangial pustules on the undersurface of leaves, on tender shoots, and occasionally on green siliquae. The affected tissue turns necrotic and dies. Systemic infection is usually seen in young inflorescences and terminal leaves. The pathogen stimulates hypertrophy and hyperplasia resulting in abnormal swelling and malformation of the affected organs. Floral organs turn green, become greatly enlarged and distorted, and seed formation is prevented (see Fig. $1 a, b$ ). Oospores are found in all infected tissues. The disease causes serious loss in yield (Bains \& Jhooty, 1979; Verma \& Bhowmik, 1989).

It is often difficult to carry out research investigations involving obligate parasites during the off-season without the help of tissue culture techniques. The possibility of growing an obligate parasite in tissue cultures of its host was first demonstrated by Morel (1944), who established

*Author for correspondence. Present address: I-1670, Chittaranjan Park, New Delhi 110019, India.
Plasmopara viticola in callus tissue of grape vine. The technique of initiating dual culture by incubating pieces of surface-sterilized, systemically infected host tissue on a callusing medium was shown by Hotson \& Cutter (1951) using juniper gall tissue incited by Gymnosporangium juniperi-virginianae and this method has since been used with other host-parasite combinations, notably Uromyces ari-triphylli and Arisaema triphyllum (Cutter, 1960), Plasmodiophora brassicae and B. oleracea var. capitata, Badger Shipper (Strandberg et al., 1966), P. brassicae and Brassica spp. (Ingram, 1969), and Cronartium ribicola and Pinus monticola (Harvey \& Grasham, 1971). The only member of the Albuginaceae grown so far in tissue culture is Albugo ipomoeaepandurata in callus tissue of Ipomoea pentaphylla (Singh, 1963). The present paper describes a technique for establishing $A$. candida in callus tissue of $B$. juncea.

\section{Methods}

Tissue culture medium. Murashige \& Skoog (1962) medium, supplied by Hi-media Laboratory (Bombay, India), was used for the establishment of callus culture of $B$. juncea. One pack of medium $(34.24 \mathrm{~g}), \mathrm{CaCl}_{2}(332.24 \mathrm{mg})$ and the required quantity of hormone(s) were dissolved in $1000 \mathrm{ml}$ distilled water. Hormones added to the medium $\left(\mathrm{mg} \mathrm{l}^{-1}\right)$ for callusing, regeneration or rooting were, respectively: benzylaminopurine, 2.0 , and indolebutyric acid, 0.4 ; benzylaminopurine, 0.8 ; and kinetin (furfurylaminopurine), $0 \cdot 2$, 

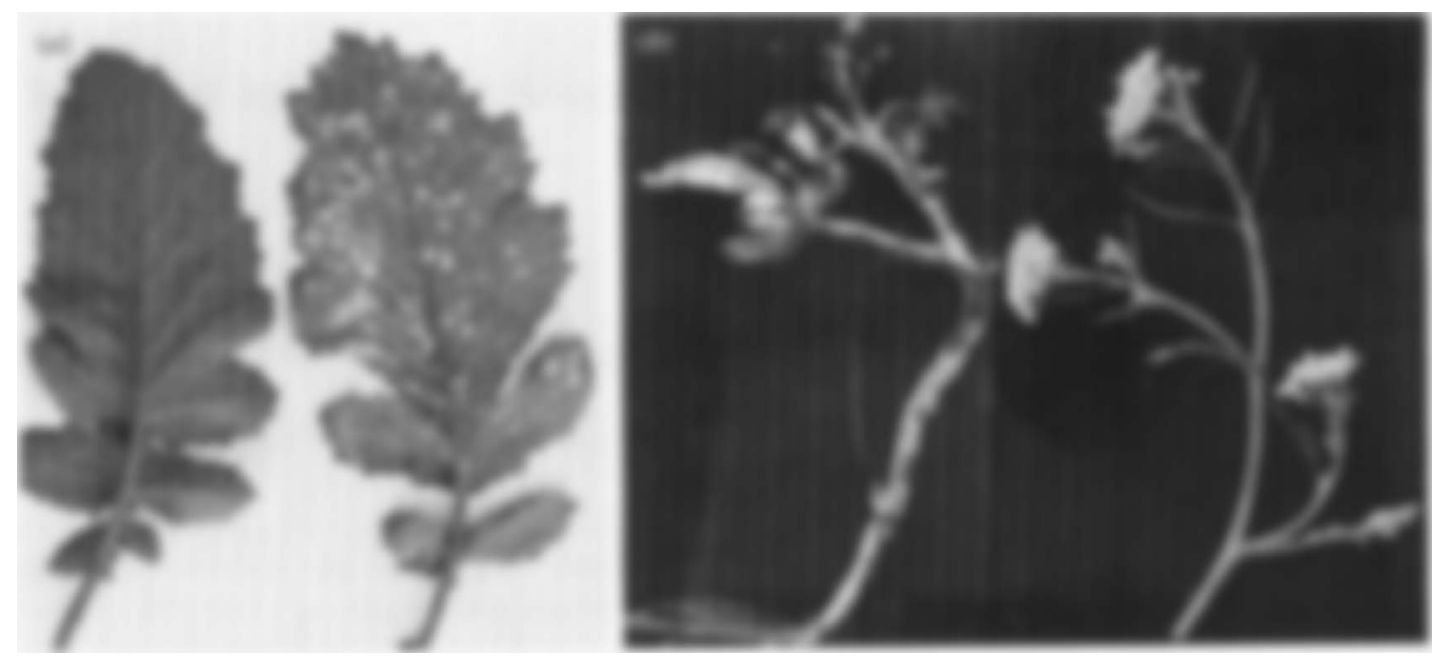

Fig. 1. (a) Healthy (left) and white-rust-infected (right) leaves of $B$. juncea. (b) White-rust-induced malformed inflorescence of $B$. juncea (left) and its healthy counterpart (right).

naphthylacetic acid, $0 \cdot 2$, and indoleacetic acid, $1 \cdot 0$. The $\mathrm{pH}$ of the solution was adjusted to 5.8 using either $0.1 \mathrm{M}-\mathrm{HCl}$ or $\mathrm{NaOH}$, heated to boiling after adding agar (bacteriological grade) to $0.8 \%(\mathrm{w} / \mathrm{v})$ and then dispensed into test-tubes and $100 \mathrm{ml}$ conical flasks at the rate of 15 and $25 \mathrm{ml}$, respectively. Sterilization was achieved by autoclaving for $15 \mathrm{~min}$ at $121^{\circ} \mathrm{C}$.

Plant material. Potted seedlings of B. juncea (cv. Pusa Bold) inoculated with sporangial suspension of $A$. candida race-2 $\left(10^{5}\right.$ sporangia ml-1) were incubated in a moist chamber for $24 \mathrm{~h}$ and then transferred to the glasshouse for white rust development. These infected plants served as the source of both sporangial inoculum and infected explants. Young hypertrophied inflorescences from fieldgrown plants as well as those obtained through inoculation of flowering shoots of potted plants (Verma \& Bhowmik, 1986) were also used as explants.

Pieces of infected leaf $(0.75 \times 0.75 \mathrm{~cm})$, hypertrophied stem $/$ peduncle $(1.5 \mathrm{~cm})$ and different organs of hypertrophied flowers were washed with distilled water, treated with $0.1 \% \mathrm{HgCl}_{2}$ solution for $2 \mathrm{~min}$, rinsed three times with distilled water and then transferred aseptically to tubes or flasks of callusing medium. Their healthy counterparts, after similar treatment, were used as controls. All specimens were incubated at $18^{\circ} \mathrm{C}$ under a low-intensity fluorescent lamp providing irradiance of $70 \mu \mathrm{E}$ $\mathrm{m}^{-2} \mathrm{~s}^{-1}$

Twenty-day-old callus tissue pieces $(0.75 \times 0.75 \mathrm{~cm})$ were fixed in formalin/acetic acid/ethanol (Johansen, 1940), dehydrated in ethanol and embedded in paraffin wax (m.p. $56-58^{\circ} \mathrm{C}$ ). Sections $(13 \mu \mathrm{m})$ were passed through xylol and hydrating alcohol series and finally stained with lactophenol/cotton blue for microscopic study.

Production of healthy callus and plantlets. After their transfer to the callusing medium, leaf and stem pieces responded by a gradual change of their colour to lighter green and a thickening of tissues. Their cut edges turned yellowish white within a week and produced small nodules of white glistening cells. Proper callusing was noticeable after another 4 to $5 \mathrm{~d}$ and the entire explant gradually turned into a cellular mass. The callus continued to increase in size by producing fresh cells; the growth rate declined with age and after about $25 \mathrm{~d}$, the callus started browning unless subcultured.

Maintenance of a callus on the regenerating medium for 2 to 3 weeks, followed by its transfer to the rooting medium, led to the production of plantlets. Shoot formation started when the callus was $15-20 \mathrm{~d}$ old. Roots and shoots often formed in the callusing medium itself.
In vitro inoculation. Leaf pieces with young, unruptured rust pustules as well as those with freshly ruptured ones were surface-sterilized and their sporangial mass harvested with a sharp lancet needle under aseptic conditions. Sporangia from a single pustule only were used to inoculate a healthy callus or a plantlet to avoid contamination. A drop of sterile water was placed on the inoculated surface to facilitate sporangial germination and infection by the resulting zoospores. Inoculated tubes/flasks were incubated at $18^{\circ} \mathrm{C}$.

\section{Results}

Inoculation of healthy host callus or regenerated plantlets with $A$. candida sporangia obtained from surfacesterilized young (unruptured) or mature (ruptured) pustules failed to establish infection; the latter practice invariably yielded bacterial and fungal contaminants. Transfer of white-rust-inoculated leaf pieces to media tubes also did not result in callus formation, although incipient tissue thickening was observed in a few cases. Similarly, leaf pieces cut out from the margin of rust pustules failed to yield positive results but in cases where minute young pustules were present on their surface, these gradually matured and released the spore mass into the medium while the explants eventually turned brown and died.

Hypertrophied floral organs differed in their growth response in the callusing medium. Sepals, petals and anthers gradually withered away while the ovary showed positive but poor callusing response. In contrast, explants from the distorted terminal leaf showed good, and those from the swollen peduncle showed excellent, callusing ability. Among the various contaminants encountered, Peronospora parasitica was the most common.

A callus derived from systemically infected peduncle grew faster than that obtained from its healthy counterpart (Fig. 2), although the two were superficially alike. 


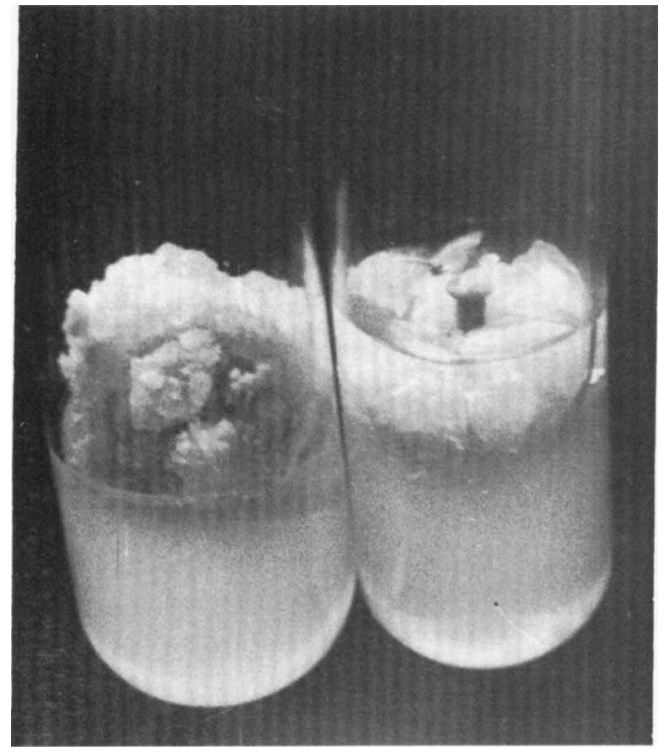

Fig. 2. Comparative growth of callus tissues from systemically infected (left) and healthy (right) inflorescence axis (peduncle) of $B$. juncea on Murashige and Skoog medium after 3 weeks.

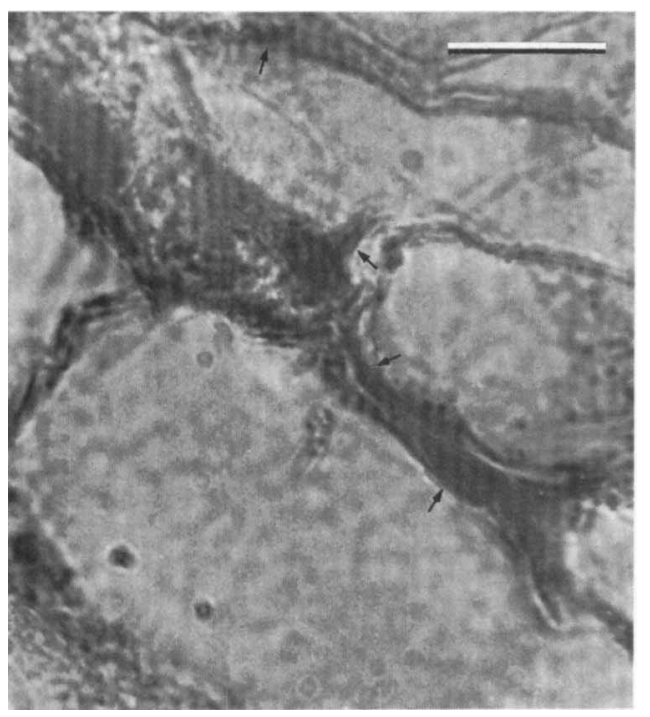

Fig. 3. Callus cells showing intercellular hypha (arrowed) of $A$. candida. Bar, $20 \mu \mathrm{m}$.

The increase in the mean size and fresh weight of ten $A$. candida-infected calluses after $15 \mathrm{~d}$ growth at $18^{\circ} \mathrm{C}$ was, respectively, $1790 \%$ and $1340 \%$, while the corresponding mean figure for ten healthy calluses during the same period was, respectively, $433 \%$ and $793 \%$. Thereafter, the growth rate of the infected callus gradually declined and only a marginal increase in its size was observed on the 25th day, while the healthy callus grew into a large cellular mass during this period. Finally, the callus in both cases gradually turned brown and died unless subcultured into fresh medium. Callus maintained at 15 , 20 and $25^{\circ} \mathrm{C}$ required subculturing after 25,20 and $15 \mathrm{~d}$, respectively, for optimum regeneration.

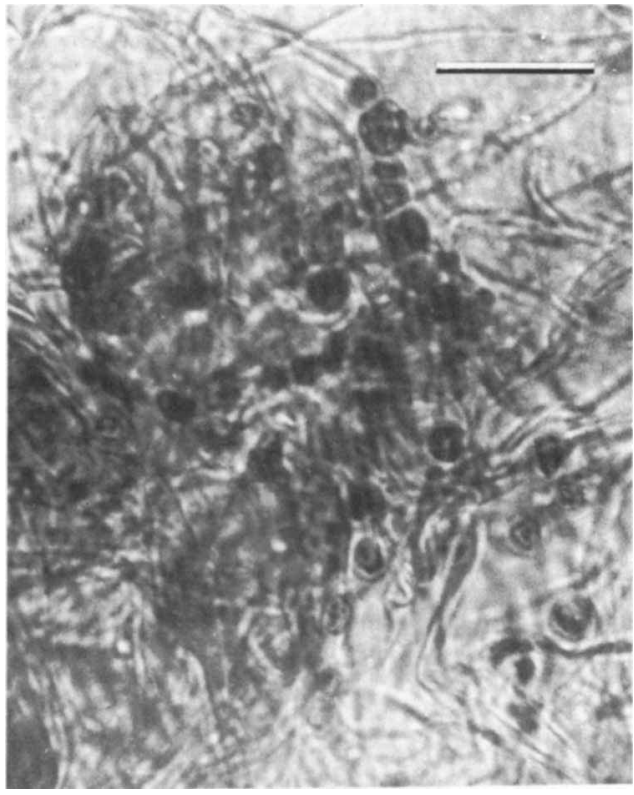

Fig. 4. Sporangial chain of $A$. candida in callus tissue. Bar, $20 \mu \mathrm{m}$.

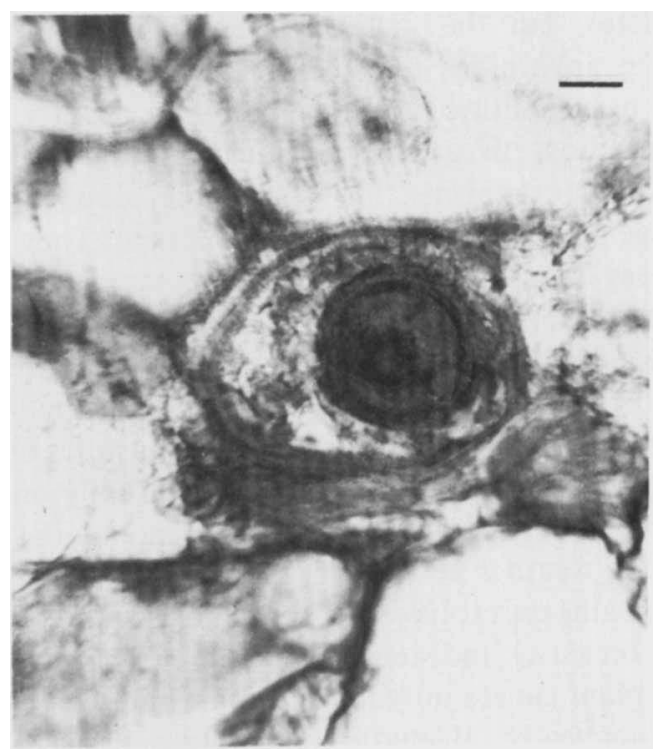

Fig. 5. A. candida oospore in the intercellular space of callus tissue. Bar, $20 \mu \mathrm{m}$.

Infected callus showed large thin-walled cells with only a few intercellular spaces and abundant coenocytic intercellular mycelium (Fig. 3) with spherical haustoria of the pathogen that penetrated the host cell walls, more than one haustorium often invading a single host cell. Sporangial chains formed on swollen ends of short hyphae were like those of $A$. candida found in naturally infected host tissue. These chains (Fig. 4) remained confined within the callus tissue, and did not protrude, but they broke easily during sectioning due to the unorganized nature of the soft callus tissue. Oospores were intercellular (Fig. 5). Infected calluses maintained at 15 and $20^{\circ} \mathrm{C}$ for 3 weeks contained only sporangial 
chains while those maintained at 25 and $30^{\circ} \mathrm{C}$ showed both sporangia and oospores.

The pathogen could be maintained in the infected callus tissue for prolonged periods at $18{ }^{\circ} \mathrm{C}$ through subculturing into fresh medium at $15-20 \mathrm{~d}$ intervals; the growth of the pathogen kept pace with that of the callus tissue. Placement of the dual culture in close contact with a healthy callus did not result in infection of the latter.

\section{Discussion}

The need for the present study arose from difficulties encountered in maintaining cultures of $A$. candida on its host plants during the off-season in the absence of growth-chamber facilities. In vitro inoculation of callus tissue/plantlets of $B$. juncea with $A$. candida sporangia obtained from unruptured pustules did not establish infection, possibly because of the failure of the spores to germinate, but the fact that sporangia from mature pustules invariably resulted in contamination of the callus tissue culture indicates high vulnerability of rustinfected host tissue to the invasion and growth of secondary organisms, of which the downy mildew pathogen $P$. parasitica is the most frequent. They seem to gain easy entry into the host through open pustules since contamination is greatly reduced when pustule-free young hypertrophied tissues are used for the production of dual culture. This also explains the occasional growth of $P$. parasitica in and around the rust pustules on leaves during the mid-season and almost invariably on hypertrophied inflorescences towards the end of the season when the weather gets warm and humid.

It remains unresolved why the white rust infection that occurs on leaves and stems during the early growth phase of the plant causes only local lesions, and why it is only the systemically infected hypertrophied tissue, and not that with localized lesions, that is suitable for the production of dual culture. Perhaps low levels of auxin/cytokinin or the presence of an inhibitory substance in leaves and stems of young plants hinders the systemic progress of the pathogen in them and their callusing ability when used as explants. The physiological condition of the flowering shoot, on the other hand, seems to be very suitable for $A$. candida to cause systemic infection and ramification within its tissues. This in turn might stimulate the production of free auxins (Hirata, 1954; Kiermayer, 1958) responsible for rapid enlargement and multiplication of host cells. This assumption is supported by the fact that the growth rate of the infected callus was much faster than that of its healthy counterpart. Tissue culture technique will be of value in elucidating the role of phytohormone(s) and/or of other factors involved in the establishment of a balanced relationship between the biotroph and its host.

Interestingly, placement of pieces of $A$. candidainfected callus tissue in close contact with a healthy callus did not result in infection of the latter, although such a method was successfully used by Griffin \& Coley-Smith (1968) in the case of Pseudoperonosopora humuli/hop stem and by Tiwari \& Arya (1969) in the case of Sclerospora graminicola/pearl millet systems. However, attempts should be made to reinfect normally grown Brassica plants using callus dual culture as the source of inoculum to evade the problem of maintaining the obligate parasite during the non-crop season.

\section{References}

BAINS, S. S. \& Jнооту, J. S. (1979). Mixed infections by Albugo candida and Peronospora parasitica on Brassica juncea inflorescence and their control. Indian Phytopathology 32, 268-271.

CUTTER, V. M. (1960). Studies on the isolation and growth of plant rusts in plant tissue cultures and upon synthetic media. II. Uromyces ari-triphylli. Mycologia 52, 726-742.

GRIfFIN, M. J. \& ColeY-Smith, J. R. (1968). The establishment of hop tissue cultures and their infection by downy mildew Pseudoperonospora humuli (Miy. \& Tak.) Wilson under aseptic conditions. Journal of General Microbiology 53, 231-236.

HaRvey, A. E. \& Grasham, J. L. (1971). Inoculation of a non-host tissue culture with Cronartium ribicola. Canadian Journal of Botany 49, 881-882.

HIRATA, S. (1954). Studies on the phytohormone in malformed portion of the diseased plants. $I$. The relation between the growth rate and the amount of free auxin in fungus galls and virus infected plants. Annals of the Phytopathological Society of Japan 19, 33-38.

Hotson, H. H. \& CUTTER, V. M. (1951). The isolation and culture of Gymnosporangium juniperi-viriginianae. Proceedings of the National Academy of Sciences of the United States of America 37, 400-403.

INGRAM, D. S. (1969). Growth of Plasmodiophora brassicae in host callus. Journal of General Microbiology 55, 9-18.

Johansen, D. A. (1940). Plant Microtechnique. New York: McGraw Hill.

KIERMAYER, O. (1958). Paper chromatographic studies of the growth substances of Capsella bursa-pastoris after infection by Albugo candida and Peronospora parasitica. Österreichische Botanische Zeitschrift 105, 515-528.

MoReL, G. (1944). Le développement du mildiou sur des tissus de vigne cultivés in vitro. Comptes Rendus Hebdomadaires des Séances de l'Academie des Sciences, Paris 218, 50-52.

Murashige, T. \& SKOOG, F. (1962). A revised medium for rapid growth and bioassays with tobacco tissue cultures. Physiologia Plantarum 15, 473-497.

SingH, H. (1963). The growth of Albugo in the callus culture of Ipomoea. Current Science 10, 472-473.

StrandberG, J. O., Williams, P. H. \& Yukawa, Y. (1966). Monoaxenic culture of Plasmodiophora brassicae with cabbage tissue. Phytopathology 56, 903 (abstract).

TIWARI, M. H. \& ARYA, H. C. (1969). Sclerospora graminicola axenic culture. Science 163, 291-293.

VERMA, U. \& BHOWMIK, T. P. (1986). A simple method of inoculating white rust on rapeseed and mustard. International Journal of Tropical Plant Disease 4, 41-43.

VERMA, U. \& BHOWMIK, T. P. (1989). Inheritance of resistance to a Brassica juncea pathotype of Albugo candida in B. napus. Canadian Journal of Plant Pathology 11, 443-444. 